Premodern Korean Literary Prose 



\title{
Premodern Korean Literary Prose
}

\author{
AN ANTHOLOGY
}

Edited by Michael J. Pettid, Gregory N. Evon, and Chan E. Park

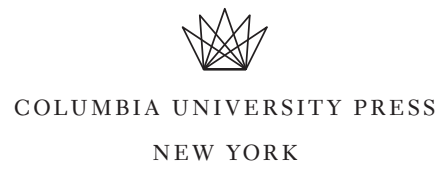


This book is published with the support of the Literature Translation Institute of Korea (LTI Korea).

Columbia University Press wishes to express its appreciation for assistance given by the Pushkin Fund in the publication of this book.

Columbia University Press

Publishers Since 1893

New York Chichester, West Sussex

cup.columbia.edu

Copyright (C) 2018 Columbia University Press

All rights reserved

Library of Congress Cataloging-in-Publication Data

Names: Pettid, Michael J. editor. | Evon, Gregory N. editor. | Park, Chan E. editor.

Title: Premodern Korean literary prose : an anthology / edited by Michael J. Pettid,

Gregory N. Evon, and Chan E. Park.

Description: New York : Columbia University Press, 2017. | Includes bibliographical references and index.

Identifiers: LCCN 2017020193 (print) | LCCN 2017031019 (ebook) | ISBN 9780231546010

(electronic) | ISBN 9780231165808 (cloth : alk. paper) | ISBN 9780231165815 (pbk.) |

ISBN $9780231546010(\mathrm{eb})$

Subjects: LCSH: Korean prose literature-Translations into English.

Classification: LCC PL984.E8 (ebook) | LCC PL984.E8 P84 2017 (print) | DDC 895.7/1-dc23

LC record available at https://ccn.loc.gov/2017020193

Columbia University Press books are printed

on permanent and durable acid-free paper.

Printed in the United States of America

Cover image: Courtesy of National Folk Museum of Korea 